\title{
Leader Affective Displays and Attributions of Charisma: The Role of Arousal
}

\section{Frederic Damen, Daan van Knippenberg and Barbara van Knippenberg}

\begin{tabular}{|l|l|}
\hline \multicolumn{2}{|l|}{ ERIM REPORT SERIES RESEARCH IN MANAGEMENT } \\
\hline ERIM Report Series reference number & ERS-2007-067-ORG \\
\hline Publication & October 2007 \\
\hline Number of pages & 32 \\
\hline Persistent paper URL & http://hdl.handle.net/1765/10621 \\
\hline Email address corresponding author & fdamen@rsm.nl \\
\hline Address & Erasmus Research Institute of Management (ERIM) \\
& RSM Erasmus University / Erasmus School of Economics \\
& Erasmus Universiteit Rotterdam \\
& P.O.Box 1738 \\
& 3000 DR Rotterdam, The Netherlands \\
& Phone: $\quad+31104081182$ \\
& Fax: $\quad+31104089640$ \\
& Email: info@erim.eur.nl \\
& Internet: $\quad$ www.erim.eur.nl \\
\hline
\end{tabular}

Bibliographic data and classifications of all the ERIM reports are also available on the ERIM website: www.erim.eur.nl 


\section{ERASMUS RESEARCH INSTITUTE OF MANAGEMENT}

\section{REPORT SERIES}

\section{RESEARCH IN MANAGEMENT}

\begin{tabular}{|l|l|}
\hline \multicolumn{2}{|l|}{ ABSTRACT AND KEYWORDS } \\
\hline Abstract & $\begin{array}{l}\text { Research suggests that leader displays of positive affect are conducive to attributions of } \\
\text { charisma. We qualify and extend this conclusion by arguing that this mainly holds for displays of } \\
\text { positive affect that are associated with high levels of arousal. Results of a scenario experiment } \\
\text { and a survey support this hypothesis, and show that besides the transfer of positive feelings per } \\
\text { se, it is the transfer of arousal that mediates the relationship between leader affective displays } \\
\text { and attributions of charisma. }\end{array}$ \\
\hline Free Keywords & $\begin{array}{l}\text { Charisma, Leader Affect, Arousal, Positive Feelings } \\
\text { Availability }\end{array}$ \\
$\begin{array}{l}\text { The ERIM Report Series is distributed through the following platforms: } \\
\text { Academic Repository at Erasmus University (DEAR), DEAR ERIM Series Portal } \\
\text { Social Science Research Network (SSRN), SSRN ERIM Series Webpage } \\
\text { Research Papers in Economics (REPEC), REPEC ERIM Series Webpage }\end{array}$ \\
\hline Classifications & $\begin{array}{l}\text { The electronic versions of the papers in the ERIM report Series contain bibliographic metadata } \\
\text { by the following classification systems: } \\
\text { Library of Congress Classification, (LCC) } \underline{\text { LCC Webpage }} \\
\text { Journal of Economic Literature, (JEL), JEL Webpage } \\
\text { ACM Computing Classification System CCS Webpage } \\
\text { Inspec Classification scheme (ICS), ICS Webpage }\end{array}$ \\
\hline
\end{tabular}


Leader Affect and Attributions of Charisma 1

Running Head: LEADER AFFECT AND ATTRIBUTIONS OF CHARISMA

Leader Affective Displays and Attributions of Charisma: The Role of Arousal 


\section{Summary}

Research suggests that leader displays of positive affect are conducive to attributions of charisma. We qualify and extend this conclusion by arguing that this mainly holds for displays of positive affect that are associated with high levels of arousal. Results of a scenario experiment and a survey support this hypothesis, and show that besides the transfer of positive feelings per se, it is the transfer of arousal that mediates the relationship between leader affective displays and attributions of charisma.

Keywords: Charisma, Leader Affect, Arousal, Positive Feelings 
Leader Affective Displays and Attributions of Charisma: The Role of Arousal Leadership has traditionally been studied mostly from a cognitive perspective (cf. Lord \& Brown, 2004; Yukl, 2002). Increasingly, however, research is focusing on the role of affect in leadership processes (e.g., Ashkanasy \& Daus, 2002; Brief \& Weiss, 2002; Dasborough \& Ashkanasy, 2002; Fitness, 2000; Glomb \& Hulin, 1997; Lord \& Brown, 2004; Sy, Côté, \& Saavedra, 2005). Leaders' displays of affect (i.e., emotions, moods) in particular have been quoted as an ingredient of charismatic leadership and a determinant of leadership effectiveness (Bass, 1985; Bono \& Ilies, 2006; Conger \& Kanungo, 1998; Sy et al., 2005). The main conclusion emerging from this research is that leader display of positive affect (as compared with negative affect or no affect) adds to attributions of charisma and leadership effectiveness (Bono \& Ilies, 2006; Gaddis, Connelly, \& Mumford, 2004; Newcombe \& Ashkanasy, 2002).

Affect can be described not only in terms of its valence, however, but also in terms of its level of associated arousal (Larsen, Diener, \& Lucas, 2002; Russell, 1980), and in the present study we qualify and extend the conclusions from previous research, arguing that the results from previous studies apply mainly to displays of positive affect that are associated with high levels of arousal (e.g., enthusiasm). We present the results of a scenario experiment and a survey of leadership in organizations supporting this hypothesis. Moreover, we show that besides the transfer of positive feelings, it is the transfer of arousal that mediates the relationship between leader affective displays and attributions of charisma. 
There is a large body of evidence suggesting that charismatic (and transformational) leadership is a particularly effective style of leadership (Conger \& Kanungo, 1998; Shamir, House, \& Arthur, 1993; Yukl, 2002). Lowe, Kroeck, and Sivasubramaniam (1996), for instance, find in a meta-analysis of 39 studies using the MLQ measure of charisma that charisma correlates between .35 and .81 with leader effectiveness, and there is also ample evidence from experimental and field studies not relying on the MLQ corroborating this conclusion (e.g., De Cremer \& van Knippenberg, 2002; Dvir, Eden, Avolio, \& Shamir, 2002; Howell \& Frost, 1989; van Knippenberg \& van Knippenberg, 2005). Several researchers also made a persuasive argument that to a certain extent charisma is in the eye of the beholder - it is an attribution to the leader made by followers (Avolio, Bass, \& Jung, 1999; Conger \& Kanungo, 1987; Meindl, 1995). Given its clear link to leadership effectiveness, it is therefore an important question for leadership research what leads followers to attribute charisma to a leader (Conger \& Kanungo, 1998).

There is emerging evidence that leader affective displays may play an important role in this respect (Bono \& Ilies, 2006; cf. Conger \& Kanungo, 1998; Meindl, 1995; Shamir \& Howell, 1999). Conceptual analyses of charismatic and transformational leadership suggest that the effectiveness of charismatic and transformational leaders derives partly from their use of emotions (Ashkanasy \& Tse, 2000; Bass, 1998; Conger \& Kanungo, 1988). Empirical studies support this point as well. In an extensive study of charismatic leadership and affect, Bono and Ilies (2006) found that charismatic leaders express more positive emotions. In a related vein, Awamleh and Gardner (1999) found that leaders who are smiling when giving a speech are perceived as more charismatic than leaders who are not 
smiling. More indirect evidence comes from studies of leader effectiveness rather than charisma that show that leader's positive affective displays are more effective than displays of negative affect (e.g., Gaddis et al., 2004; George, 1995; George \& Bettenhausen, 1990; Newcombe \& Ashkanasy, 2002). Gaddis et al. (2004) for example found that group leaders who displayed positive affect in interaction were perceived as more effective than group leaders who displayed negative affect, and George and Bettenhausen (1990) showed that leaders who are in a positive mood have a positive impact on pro-social behavior of workers and a negative impact on voluntary turnover. Furthermore, it was found that leaders who expressed positive affect in a video message were rated as giving more freedom of negotiation to followers than leaders who expressed negative emotions by observers of the video message (Newcombe \& Ashkanasy, 2002).

There is also evidence suggesting that the transfer of positive affect (cf. emotional contagion, Hatfield, Cacioppo, \& Rapson, 1992) may play a role in the relationship between leader displays of positive affect and attributions of charisma. Bono and Ilies (2006) found that leader display of positive affect predict follower positive affect, and Sy et al. (2005) found that leader positive or negative mood transferred to followers. In addition studies of charismatic and transformational leadership (that did not assess leader affective displays) show that charismatic and transformational leadership are associated with more positive follower affect and less negative follower affect than non-charismatic and transactional leadership (Cherulnik, Donley, Wiewel, \& Miller, 2001; Dvir \& Wenger, 2004). These findings point to the possibility that the transfer of positive affect mediates the relationship between leader affective displays and attributions of charisma, although 
this mediational model has to our knowledge not been tested.

Attributions of charisma or effective leadership may flow from the match between leader characteristics and follower pre-conceptions of charismatic and effective leadership (Epitropaki \& Martin, 2005; Lord, Foti, \& De Vader, 1984; Lord \& Maher, 1991; Meindl, 1995; Meindl \& Ehrlich, 1987; Meindl, Ehrlich, \& Dukerich, 1985, cf. Dasborough \& Ashkanasy, 2002). It may be assumed that the display of positive affect (more than of negative or no affect) is also part of followers' cognitive schema for charismatic leadership (cf. Meindl, 1995). Accordingly, leader displays of positive affect would match follower standards for charismatic leadership and thus render attributions of charisma more likely. In a similar vein, the experience that leader positive affect elicits positive affect in oneself may likewise match followers' conceptions of charismatic leadership and thus feed into attributions of charisma.

All studies discussed previously looked at the influence of displays of positive affect in comparison with displays of negative affect and/or no affect, but none of these studies has differentiated affective displays in terms of the associated level of arousal. We argue, however, that arousal may be as important as valence in eliciting attributions of charisma. The Arousal and Valence Dimensions of Affect and Attributions of Charisma

Research in the psychology of affect has resulted in widely recognized Affect Circumplex Models identifying two core dimensions underlying differences between affective states: a psychological (valence, pleasantness) and a physiological component (arousal, activation) (e.g., Larsen et al., 2002; Russell, 1980; Watson, Clark, \& Tellegen, 1988). Some positive affective states are associated with relatively high levels of arousal 
(e.g., enthusiasm), whereas others are associated with relatively low levels of arousal (e.g., relaxation). In a similar vein, some negative affective states are characterized by higher arousal (e.g., anger) than others (e.g., sadness). Therefore, in an attempt to understand the relationship between leader affective displays and attributions of charisma it stands to reason to not only explore the effects of the valence of the affective display, but also of the associated level of arousal.

Following the same logic that suggests that leader displays of positive affect may be part of follower conceptions of charismatic leadership (cf. Meindl, 1995) and therefore render attributions of charisma more likely, we argue that these attributions of charisma are more likely when the leader displays high arousal positive affect rather than low arousal positive affect. Conceptual analyses have associated charismatic leadership with being action-driven and able to energize followers (e.g., Bryman, 1992; Conger \& Kanungo, 1988). Moreover, the display of high arousal affect more than that of low arousal affect suggests power and competence (Tiedens, 2001; cf. Lewis, 2000), which may feed into attributions of charisma. Displaying high arousal affect may therefore be as important as displaying positive affect, and we propose that it is the combination of positiveness and high activation that leads to attributions of charisma.

Transfer of affective state may also play a role in this respect. Indeed, just as the positive and negative components of affective states may transfer from the one person to the other through emotional contagion processes, the arousal associated with affective states may also transfer from one person to the other (cf. Hatfield et al., 1992). Likewise, George $(1995,1996)$ argues, that energized, aroused states may transfer from leader to 
followers. For similar reasons as outlined above, such transfer of arousal may elicit attributions of charisma, because the feeling of being energized by a leader is likely to match follower conceptions of charismatic leadership. That is, in addition to the transfer of positive feelings, the transfer of activation may render attributions of charisma more likely.

In sum, then, extending earlier research, we predict that the display of high arousal positive affect causes stronger attributions of charisma than the display of low arousal positive affect and of (high and low arousal) negative affect. In addition, we expect that this relationship is mediated by the transfer of arousal from leader to follower as well as by the transfer of positive feelings.

We tested these predictions in a scenario experiment (Study 1) and a cross-sectional survey of leadership in organizations (Study 2). The use of these different methodologies allows us to on the one hand establish the causality implied by our analysis (Study 1) while on the other hand establishing that the predicted relationships may also be observed in the field (Study 2). Thus, the combination of methods may substantially bolster the confidence in our conclusions (cf. Dipboye, 1990; van Knippenberg, Martin, \& Tyler, 2006). As a way of operationalizing high arousal positive and negative affect we focused on enthusiasm and anger respectively (cf. Larsen et al., 2002; Russell, 1980; Watson et al., 1988). Enthusiasm and anger have both been quoted as important emotions in leadership situations (e.g., Conger \& Kanungo, 1998; George, 1995, 1996; Lewis, 2000; Tiedens, 2001). As low arousal counterparts, we focused on relaxation and sadness (cf. Lewis, 2000; Russell, 1980; Tiedens, 2001). In terms of these specific affective states, we predicted the following.

Hypothesis 1. Leader displays of enthusiasm lead to higher attributions of charisma 
than leader displays of anger, relaxation, or sadness.

Hypothesis 2. The relationship of leader displays of enthusiasm (as compared with anger, relaxation, and sadness) and attributions of charisma is mediated by transfer of arousal from leader to subordinates as well as by transfer of positive feelings.

Study 1

Method

\section{Participants and Design}

One hundred fifty-two business students participated voluntarily in this scenario experiment. The participants were randomly assigned to the four conditions (Leader Affect: enthusiasm/ anger/ relaxation/ sadness). Mean age was 20.50 years $(S D=2.16)$. Participants were paid 3 euro (approximately US \$4). Seven respondents were omitted from the analyses because of missing data.

\section{Procedure}

Participants were seated in separate cubicles and were told the study would be about "communication management". They were introduced to the scenario nature of the study, and asked to do their best to imagine themselves to be in the described situation. The scenario portrayed a situation in which employees of a small organization were spoken to by their leader. Participants were to imagine that they, as an employee of this company, listened to this leader. The leader, being the leader of the company, was giving a speech concerning the quarterly results of the company. As part of the scenario, participants read an excerpt of this speech. In all conditions, the leader announced that quarterly results had stayed stable as compared to the previous quarter, which in itself did not qualify results as 
either good or bad. Depending on the experimental condition, the leader displayed a different affective state (see below) when announcing the quarterly results. After reading the scenario, participants filled out a short questionnaire assessing reactions to leadership and manipulation checks. Finally, participants were debriefed, paid, and thanked for their participation.

\section{Manipulation of Leader Affect}

The wording of the leader's speech was identical in all conditions, aside from the affect the leader quoted to experience. Depending on the condition, the leader claimed to be enthusiastic, relaxed, angry, or sad about the quarterly results. To describe this affective state, the leader used words like "enthusiastic" and "excited" in the enthusiastic leader condition, "angry" and "nettled" in the angry leader condition, "tranquil" and "relaxed" in the relaxed leader condition, and "sad", and "dismal" in the sad leader condition. Such verbal statements of affect have been shown to effectively communicate affective states to others in (simulated) interaction (Van Kleef, De Dreu, \& Manstead, 2004a, 2004b, 2006) including in scenario experiments on affective displays (e.g., Sinaceur \& Tiedens, 2006).

\section{Measures}

For all measures, participants were asked to indicate their agreement on 5-point scales ranging from disagree completely to agree completely. To check the manipulation, participants were asked by single item measures to indicate how enthusiastic, angry, relaxed, or sad the leader was (e.g., "this leader is enthusiastic").

Perceived charisma of the leader was measured with five items $(\alpha=.87, M=2.90, S D$ $=.98)$, based on the work of Bass (1985) and Conger and Kanungo (1987). An example of 
an item is "This leader moves people towards a goal".

Transfer of arousal was measured with two items: "This leader transfers energy" and "This leader has an activating impact on me" $(r=.75, \alpha=.86, M=2.70, S D=1.18)$.

Transfer of positive feelings was measured with two items: "This leader transfers a good feeling to me" and "This leader makes me feel pleasant" $(r=.85, \alpha=.92, M=2.42$, $S D=.98)$.

\section{Results}

\section{Manipulation Checks}

Manipulation checks were analyzed in an analysis of variance. This analysis revealed an effect on the question to what extent the leader displayed enthusiasm, $F(3,141)=38.52$, $p<.001, \eta^{2}=.45$. The perceptions of leader's enthusiasm was contrasted with the perception of the other three leader affective displays and this analysis showed that in the leader's enthusiasm condition, he was indeed perceived as more enthusiastic $(M=4.29, S D$ $=.93$ ) than the other three leader affective displays (anger, $M=2.77, S D=1.20$, relaxation, $M=2.22, S D=.87$, or sadness, $M=2.00, S D=.87), t(141)=10.45, p<.001$.

An analysis on the subordinates' perceptions of the leader's display of anger showed a strong effect, $F(3,141)=86.50, p<.001, \eta^{2}=.65$. Contrast analysis revealed that a leader displaying anger was also perceived as being in a higher state of anger $(M=4.44, S D=$ .91) than leaders displaying the other three affective states (enthusiasm, $M=1.63, S D=$ .81 , relaxation, $M=1.58, S D=.73$, or sadness, $M=2.80, S D=1.05), t(141)=14.69, p<$ .001 .

Leader Affect has also an effect on perceptions of relaxation, $F(3,141)=51.07, p<$ 
$.001, \eta^{2}=.52$. Contrast analysis revealed that leaders who were relaxed, were also seen as more relaxed by participants $(M=3.94, S D=1.29)$ than the other three leader affective displays (enthusiasm, $M=2.77, S D=.94$; anger, $M=1.33, S D=.53$; sadness, $M=2.17$, $S D=.86), t(141)=10.28, p<.001$.

Leader Affect has a significant effect on perceptions of sadness, $F(3,141)=52.84, p<$ $.001, \eta^{2}=.53$. Displays of sadness contrasted with the other three leader affective displays showed that a leader displaying sadness was seen as sadder $(M=4.29, S D=.83)$ than the leaders in the other three conditions (enthusiasm, $M=1.60, S D=.81$; anger, $M=2.95, S D$ $=1.10$; relaxation, $M=2.06, \mathrm{SD}=1.07), t(141)=11.13, p<.001$.

We may therefore conclude that our manipulation of Leader Affect was successful. Charisma, Transfer of Arousal, and Transfer of Positive Feelings

An analysis of variance on perceived charisma resulted in an effect of Leader Affect, $F(3,141)=11.89, p<.001, \eta^{2}=.20$, showing that enthusiastic leaders are seen as more charismatic than angry leaders, relaxed, or sad leaders (see Table 1). We found therefore evidence for Hypothesis 1.

Analyses on transfer of arousal, showed a significant effect of Leader Affect $(F(3,141)$ $=22.19, p<.001, \eta^{2}=.32$ ). Enthusiastic leaders transferred more arousal than angry, relaxed, or sad leaders (see Table 1).

An analysis of variance on transfer of positive feelings revealed an effect of Leader $\operatorname{Affect}\left(F(3,141)=12.04, p<.001, \eta^{2}=.20\right)$. Enthusiastic leaders transfer more positive feelings than angry, relaxed or sad leaders (see Table 1).

\section{Mediation Analysis}


We hypothesized (Hypothesis 2) that the transfer of arousal and the transfer of positive feelings mediate the effect of leader display of enthusiasm (vs. anger, relaxation, or sadness) on attributions of charisma. To test this prediction, we conducted mediation analyses following Baron and Kenny (1986).

We have already shown that Leader Affect significantly influences attributions of charisma, transfer of arousal, and transfer of positive feelings. To establish whether the effects on transfer of arousal and transfer of positive feelings accounted for the effect on attributions of charisma, both transfer of arousal and transfer of positive feelings were included as covariates in the analysis of attributions of charisma. The regression was significant, $F(3,141)=112.82, p<.001, \eta^{2}=.40, \beta=.68$ (transfer of arousal), $\beta=.23$ (transfer of positive feelings). The effect of Leader Affect on perceived charisma disappeared when controlling for both transfer of arousal and transfer of positive feelings, $F(3,140)=2.10, p=.10, n s ., \eta^{2}=.04$. Two Sobel tests (Sobel, 1982) indicated that both transfer of arousal and transfer of positive feelings were significant mediators, $z=4.23, p<$ .0001 (transfer of arousal), and $z=2.48, p<.05$ (transfer of positive feelings). Hypothesis 2 is therefore confirmed.

\section{Study 2}

\section{Method}

Hundred employees of a medium-sized soft drink company, a public health organization, and the railway police were sent a survey by electronic mail with the request to rate their direct leaders, or were approached during a team meeting with this same request. Seventy-one employees (mean age 38.29 years, $S D=9.85$; response rate $71 \%$ ) 
granted the request.

Measures

Leader affect was assessed by asking respondents to rate on 5-point scales (varying from 1 = disagree completely, to $5=$ agree completely) the extent to which their direct leader tended to be relaxed, enthusiastic, angry, and sad in the workplace. Perceived charisma of the leader was measured with the same five items as in Study $1(\alpha=.90, M=$ $3.57, S D=.90)$. Transfer of arousal was measured with the same two items as in Study $1(r$ $=.55, \alpha=.71, M=3.50, S D=.86)$. Transfer of positive feelings was measured with the same two items as in Study $1(r=.76, \alpha=.86, M=3.72, S D=.87)$.

\section{Results}

Means, standard deviations, and inter-correlations for all variables are displayed in Table 2.

Charisma, Transfer of Arousal, and Transfer of Positive Feelings

The results of the regression analyses of leader affective displays on perceived charisma, transfer of arousal, and transfer of positive feelings are shown in Table 3. Results showed that leader enthusiasm was the only affective display related to perceived charisma, transfer of arousal, and transfer of positive feelings. Furthermore, tests of the regression weight for enthusiasm against the regression weights of the other affective displays showed that enthusiasm was more strongly related to attributions of charisma, transfer of arousal, and transfer of positive feelings than the other leader affective displays (see Table 3). Hypothesis 1 was therefore confirmed. Mediational Analysis 
To establish mediation, following Baron and Kenny (1986), leader affective displays must have a significant impact on the mediators (both transfer of arousal and transfer of positive feelings) and the dependent variable (perceived charisma). As we can see (Table 3), this is only the case with leader enthusiasm. The mediators must also have a significant impact on perceived charisma, which was the case. Finally, the effect of enthusiasm on perceived charisma must drop to non-significance when including both transfer of arousal and transfer of positive feelings in the regression. This was also the case (see Table 3), which was a significant decline as indicated by two Sobel tests, $z=2.65, p<.01$ (transfer of arousal), and $z=3.24, p<.01$ (transfer of positive feelings). Therefore, we can conclude that transfer of arousal and transfer of positive feelings mediate the relationship between leader displays of enthusiasm and attributions of charisma (Hypothesis 2).

\section{Discussion}

Research in leadership is getting more attuned to the role of affect in leadership processes, and the present study adds to the growing body of evidence that leader affective displays influence followers. Extending earlier work suggesting that leader displays of positive affect may engender attributions of charisma and transfer to followers, we showed that this holds mainly for leader displays of high arousal positive affect. The present study also provided the first test of a mediational model linking transfer of positive feelings to attributions of charisma. Moreover, we showed that it is not only transfer of positive feelings per se, but also transfer of arousal that mediates the relationship between displays of high arousal positive affect and attributions of charisma. 
Previous studies of leader affective displays have not distinguished between the valence and arousal associated with affective states, and especially studies distinguishing high and low arousal affective states are scarce. A key contribution of the present study therefore is that it puts the arousal dimension of affect more firmly on the agenda of leadership research (cf. van Knippenberg, van Knippenberg, Van Kleef, \& Damen, forthcoming). Arousal adds to the influence of positive affect per se, and transfer of arousal played as important a role in engendering attributions of charisma as transfer of positive feelings. The current study thus suggests that it may be worthwhile to consider the role of the arousal associated with leader affective displays in leadership processes related to leadership effectiveness (Lord \& Brown, 2004), identification with the leader (Hogg \& van Knippenberg, 2003), and attributions of power and status (Schubert, 2005; Tiedens, 2001), among others. The present findings suggest that in these processes too, arousal may augment the impact of positiveness per se.

Our hypotheses were grounded not only in theory and anecdotal evidence in charismatic leadership, but also in the notion that the display, and transfer, of high arousal positive affect might be part of followers' implicit assumptions about charismatic leadership (cf. Lord \& Maher, 1991; Meindl, 1995). While this seems to be a reasonable assumption, and indeed the present findings are consistent with this assumption, future research might explicitly assess the extent to which affective displays, and the transfer of affect, are part of people's implicit beliefs about charismatic leadership.

The finding that arousal plays an important part in the effect of leader positive affective states also has clear implications for practice. Organizations that rely heavily on employees 
adhering to expression norms (i.e., norms that dictate which and how emotions may be expressed, cf. Hochschild, 1983; Kemper, 2000; Zapf, 2002), as for instance call centers, may benefit from the notion that arousal may be just as an important aspect of affect as valence. Indeed, expression norms often originate from the idea that employees' expression of positive emotions ensures positive feelings of customers or prospects, which in the end leads to higher sales. It may be that especially employees' display of high arousal positive emotions may lead customers to see the organizational representatives in a positive light, which in turn may result in employees being more effective in their dealings with customers. Of course, the present study also implies that leaders may benefit from a stronger focus on arousal. Leaders displaying positive arousal (i.e., an energized, enthusiastic state) may be more effective, and leadership training could explicitly address the importance of arousal in communication with followers.

The present study is not without its limitations. Clearly it is a strength that we combined scenario experimental and field data, because the strength of the one method may compensate for the weakness of the other (Dipboye, 1990; van Knippenberg et al., 2006), and the use of two different methodologies led to the same conclusions regarding our hypotheses. Whereas the scenario experiment allows for conclusions about causality and yet maintains a relatively high degree of mundane realism, it does describe a hypothetical situation. This aspect of our first study makes the replication in the field important. Conversely, due to its cross-sectional nature the field study is mute in matters of causality and susceptible to common method bias, and the first scenario experiment is important in addressing these shortcomings. The replication in the field may also be argued 
to be important vis-à-vis our manipulation of leader affective displays (i.e., written statement of affect). While verbal statements of affect have been shown to be effective in conveying affective states (Johnson \& Tversky, 1983; Sinaceur \& Tiedens, 2006; Van Kleef et al., 2004a, 2004b, 2006), an important part of affective displays is nonverbal and the field data may be assumed to also reflect the influence of these nonverbal aspects of affective displays.

Even though scenario experiments in leadership typically yield results that are replicated in the lab as well as in the field (De Cremer \& van Knippenberg, 2002, 2004; De Cremer, van Knippenberg, van Knippenberg, Mullenders, \& Stinglhamber, 2005; van Knippenberg \& van Knippenberg, 2005), from the perspective of obtaining strong experimental evidence it would be valuable if future research would replicate and extend the current findings in a non-hypothetical experimental set-up in which participants are actually immersed in the leadership situation. Ideally, such an experimental set-up would also allow for the assessment of the transfer of arousal through physiological rather than self-report measures that would increase measurement quality and thus further strengthen the confidence in our findings. In a related vein, follow-up research in the field that combines different data sources would provide a valuable extension of the current findings.

In addition, we should note that while our theoretical analysis concerns valence and arousal in general, our empirical work was limited to four specific instances of high versus low, positive versus negative leader affective displays. While these affective displays were representative of the four quadrants distinguished by Affect Circumplex Models (Larsen et al., 2002; Russell, 1980), we cannot exclude the possibility that the present findings are 
limited to the four distinct affective displays under consideration. Therefore, a replication with other affective displays would give us more insights into the effects of leader affect and would bolster our argument. The bottom line is, however, that the present findings provide an important point of departure for future studies of leader affective displays that are not only attuned to the valence of leader affective displays, but also to the interplay of valence and arousal in affecting followers. 


\section{References}

Ashkanasy, N. M., \& Tse, B. (2000). Transformational leadership as management of emotion: A conceptual review. In N. M. Ashkanasy, E. J. Härtel, \& W. J. Zerbe (Eds.), Emotions in the workplace: Research, theory and practice (pp. 221-235). Westport, CT: Quorum Books.

Ashkanasy, N. M., \& Daus, C. S. (2002). Emotion in the workplace: The new challenge for managers. Academy of Management Executive, 16, 76-86.

Avolio, B. J., Bass, B. M., \& Jung, D. I. (1999). Re-examining the components of transformational and transactional leadership using the Multifactor Leadership Questionnaire. Journal of Occupational and Organizational Psychology, 72, 441-462.

Awamleh, R., \& Gardner, W. L. (1999). Perceptions of leader charisma and effectiveness: The effects of vision, content, delivery, and organizational performance. Leadership Quarterly, 10, 345-373.

Baron, R. M., \& Kenny, D. A. (1986). The moderator-mediator variable distinction in social psychological research: Conceptual, strategic, and statistical considerations. Journal of Personality and Social Psychology, 51, 1173-1182.

Bass, B. M. (1985). Leadership and performance beyond expectations. New York, NY: Free Press.

Bass, B. M. (1998). Transformational leadership: Industrial, military, and educational impact. Mahwah, NJ: Erlbaum.

Bono, J. E., \& Ilies, R. (2006). Charisma, positive emotions and mood contagion. Leadership Quarterly, 17, 317-334. 
Brief, A. P., \& Weiss, H. M. (2002). Organizational behavior: Affect in the workplace. Annual Review of Psychology, 53, 279-307.

Bryman, A. (1992). Charisma and leadership in organizations. London: Sage.

Cherulnik, P. D., Donley, K. A., Wiewel, T. S. R., \& Miller, S. R. (2001). Charisma is contagious: The effect of leaders' charisma on observers' affect. Journal of Applied Social Psychology, 31, 2149-2159.

Cohen, J., \& Cohen, P. (1983). Applied multiple regression/correlation analysis for the behavioral sciences ( $2^{\text {nd }}$ ed.). Hillsdale, $\mathrm{NJ}$ : Erlbaum.

Conger, J. A., \& Kanungo, R. N. (1987). Toward a behavioral theory of charismatic leadership in organizational settings. Academy of Management Review, 12, 637-647.

Conger, J. A., \& Kanungo, R. N. (1988). Charismatic Leadership: The elusive factor in organizational effectiveness. San Francisco, CA: Jossey-Bass.

Conger, J. A., \& Kanungo, R. N. (1998). Charismatic leadership in organizations. Thousand Oaks, CA: Sage.

Dasborough, M. T., \& Ashkanasy, N. M. (2002). Emotion and attribution of intentionality in leader-member relationships. Leadership Quarterly, 13, 615-634.

De Cremer, D., \& van Knippenberg, D. (2002). How do leaders promote cooperation? The effects of charisma and procedural fairness. Journal of Applied Psychology, 87, 858-866.

De Cremer, D., \& van Knippenberg, D. (2004). Leader self-sacrifice and leadership effectiveness: The moderating role of leader self-confidence. Organizational Behavior and Human Decision Processes, 95, 140-155.

De Cremer, D., van Knippenberg, B., van Knippenberg, D., Mullenders, D., \& 
Stinglhamber, F. (2005). Rewarding leadership and fair procedures as determinants of self-esteem. Journal of Applied Psychology, 90, 3-12.

Dipboye, R. L. (1990). Laboratory vs. field research in industrial and organizational psychology. In C. L. Cooper \& I. T. Robertson (Eds.), International Review of Industrial and Organizational Psychology (Vol. 5, pp. 1-34). Chichester, UK: John Wiley \& Sons.

Dvir, T., Eden, D., Avolio, B. J., \& Shamir, B. (2002). Impact of transformational leadership on follower development and performance: A field experiment. Academy of Management Journal, 45, 735-744.

Dvir, T., \& Wenger, I. (2004, April). Leadership, follower emotions, and performance: An experimental examination. Study presented at the $19^{\text {th }}$ Annual Meeting of the Society for Industrial and Organizational Psychology, Chicago, 2004

Epitropaki, O., \& Martin, R. (2005). From ideal to real: A longitudinal study of the role of implicit leadership theories on leader-member exchanges and employee outcomes. Journal of Applied Psychology, 90, 659-676.

Fitness, J. (2000). Anger in the workplace: An emotion script approach to anger episodes between workers and their superiors, co-workers and subordinates. Journal of Organizational Behavior, 21, 147-162.

Gaddis, B., Connelly, S., \& Mumford, M. D. (2004). Failure feedback as an affective event: Influence of leader affect on subordinate attitudes and performance. Leadership Quarterly, 15, 663-686.

George, J. M. (1995). Leader positive mood and group performance: The case of customer 
service. Journal of Applied and Social Psychology, 25, 778-794.

George, J. M. (1996). Group affective tone. In M. A. West (Ed.), Handbook of Work Group Psychology (pp. 77-93). Chichester, UK: John Wiley \& Sons.

George, J. M., \& Bettenhausen, K. (1990). Understanding prosocial behavior, sales performance, and turnover: A group-level analysis in a service context. Journal of Applied Psychology, 75, 698-709.

Glomb, T. M., \& Hulin, C. L. (1997). Anger and gender effects in observed supervisorsubordinate dyadic interactions. Organizational Behavior and Human Decision Processes, 72, 281-307.

Hatfield, E., Cacioppo, J. T., \& Rapson, R. L. (1992). Primitive emotional contagion. In M. S. Clark (Ed.), Emotion and social behavior (pp. 151-175). Newbury Park, CA: Sage. Hochschild, A. R. (1983). The managed heart: The commercialization of human feeling. Berkeley, CA: University of California Press.

Hogg, M. A., \& van Knippenberg, D. (2003). Social identity and leadership processes in groups. In M. P. Zanna (Ed.), Advances in experimental social psychology (pp. 2-55). New York, NY: Academic Press.

Howell, J. M., \& Frost, P. J. (1989). A laboratory study of charismatic leadership. Organizational Behavior and Human Decision Processes, 43, 243-269.

Johnson, E. J., \& Tversky, A. (1983). Affect, generalization, and the perception of risk. Journal of Personality and Social Psychology, 45, 20-31.

Kemper, T. D. (2000). Social models in the explanation of emotions. In M. Lewis \& J. M. Haviland-Jones (Eds.), Handbook of emotions (2 ed., pp. 45-58). New York: Guilford 
Press.

Larsen, R. J., Diener, E., \& Lucas, R. E. (2002). Emotion: Models, measures, and individual differences. In R. G. Lord, R. J. Klimoski, \& R. Kanfer (Eds.), Emotions in the workplace: Understanding the structure and role of emotions in organizational behavior (pp. 64-106). San Francisco, CA: Jossey-Bass.

Lewis, K. M. (2000). When leaders display emotion: How followers respond to negative emotional expression of male and female leaders. Journal of Organizational Behavior, $21,221-234$.

Lord, R. G. \& Brown, D. J. (2004). Leadership processes and follower self-identity. Mahwah, NJ: Erlbaum.

Lord, R. G., Foti, R. J., \& De Vader, C. L. (1984). A theory of leadership categorization theory: Internal structure, information processing, and leadership perceptions. Organizational Behavior and Human Performance, 34, 343-378.

Lord, R. G., \& Maher, K. J. (1991). Leadership and information processing. Boston, MA: Routledge.

Lowe, K. B., Kroeck, K. G., \& Sivasubramaniam, N. (1996). Effectiveness correlates of transformational and transactional leadership: A meta-analytic review of the MLQ literature. Leadership Quarterly, 7, 385-425.

Meindl, J. R. (1995). The romance of leadership as a follower-centric theory: A social constructionist approach. Leadership Quarterly, 6, 329-341.

Meindl, J. R., \& Ehrlich, S. B. (1987). The romance of leadership and the evaluation of organizational performance. Academy of Management Journal, 30, 91-109. 
Meindl, J. R., Ehrlich, S. B., \& Dukerich, J. M. (1985). The romance of leadership. Administrative Science Quarterly, 30, 78-102.

Newcombe, M. J., \& Ashkanasy, N. M. (2002). The role of affect and affective congruence in perceptions of leaders: An experimental study. Leadership Quarterly, 13, 601-614.

Russell, J. A. (1980). A circumplex model of affect. Journal of Personality and Social Psychology, 39, 1161-1178.

Schubert, T. W. (2005). Your Highness: Vertical Positions as Perceptual Symbols of Power. Journal of Personality and Social Psychology, 89, 1-21.

Shamir, B., House, R. J., \& Arthur, M. B. (1993). The motivational effects of charismatic leadership: A self-concept based theory. Organization Science, 4, 577-594.

Shamir, B., \& Howell, J. M. (1999). Organizational and contextual influence on the emergence and effectiveness of charismatic leadership. Leadership Quarterly, 10, 257283

Sinaceur, M., \& Tiedens, L. Z (2006). Get mad and get more than even: When and why anger expression is effective in negotiations. Journal of Experimental Social Psychology, 42, 314-322.

Sobel, M. E. (1982). Asymptotic confidence intervals for indirect effects in structural equations models. In S. Leinhardt (Ed.), Sociological Methodology 1982 (Vol 13, pp. 290-312). San Francisco, CA: Jossey-Bass.

Sy, T., Côté, S., \& Saavedra, R. (2005). The contagious leader: Impact of the leader's mood on the mood of group members, group affective tone, and group processes. Journal of Applied Psychology, 90, 295-305. 
Tiedens, L. Z. (2001). Anger and advancement versus sadness and subjugation: The effect of negative emotion expressions on social status conferral. Journal of Personality and Social Psychology, 80, 86-94.

Van Kleef, G. A., De Dreu, C. K. W., \& Manstead, A. S. R. (2004a). The interpersonal effects of anger and happiness in negotiations. Journal of Personality and Social Psychology, 86, 57-76.

Van Kleef, G. A., De Dreu, C. K. W., \& Manstead, A. S. R. (2004b). The interpersonal effects of emotions in negotiations: A motivated information processing approach. Journal of Personality and Social Psychology, 87, 510-528.

Van Kleef, G. A., De Dreu, C. K. W., \& Manstead, A. S. R. (2006). Supplication and appeasement in conflict and negotiation: The interpersonal effects of disappointment, worry, guilt, and regret. Journal of Personality and Social Psychology, 91, 124-142.

van Knippenberg, B., Martin, L., \& Tyler, T. (2006). Process-orientation versus outcomeorientation during organizational change: The role of organizational identification. Journal of Organizational Behavior, 27, 685-704.

van Knippenberg, B., \& van Knippenberg, D. (2005). Leader self-sacrifice and leadership effectiveness: The moderating role of leader prototypicality. Journal of Applied Psychology, 90, 25-37.

van Knippenberg, D., van Knippenberg, B., Van Kleef, G. A., \& Damen, F. (forthcoming).To appear in C. L. Cooper, \& N. M. Ashkanasy (Eds.), Research companion to emotion in organizations. London: Edward Elgar.

Watson, D., Clark, L. A., \& Tellegen, A. (1988). Development and validation of brief 
measures of positive and negative affect: The PANAS scales. Journal of Personality and Social Psychology, 54, 1063-1070.

Yukl, G. (2002). Leadership in organizations ( $5^{\text {th }}$ ed.). Upper Saddle River, NJ: Prentice Hall.

Zapf, D. (2002). Emotion work and psychological well-being: A review of the literature and some conceptual considerations. Human Resource Management Review, 12, 237268. 
Table 1

Means, Standard Deviations, and Comparison of Means, Study 1.

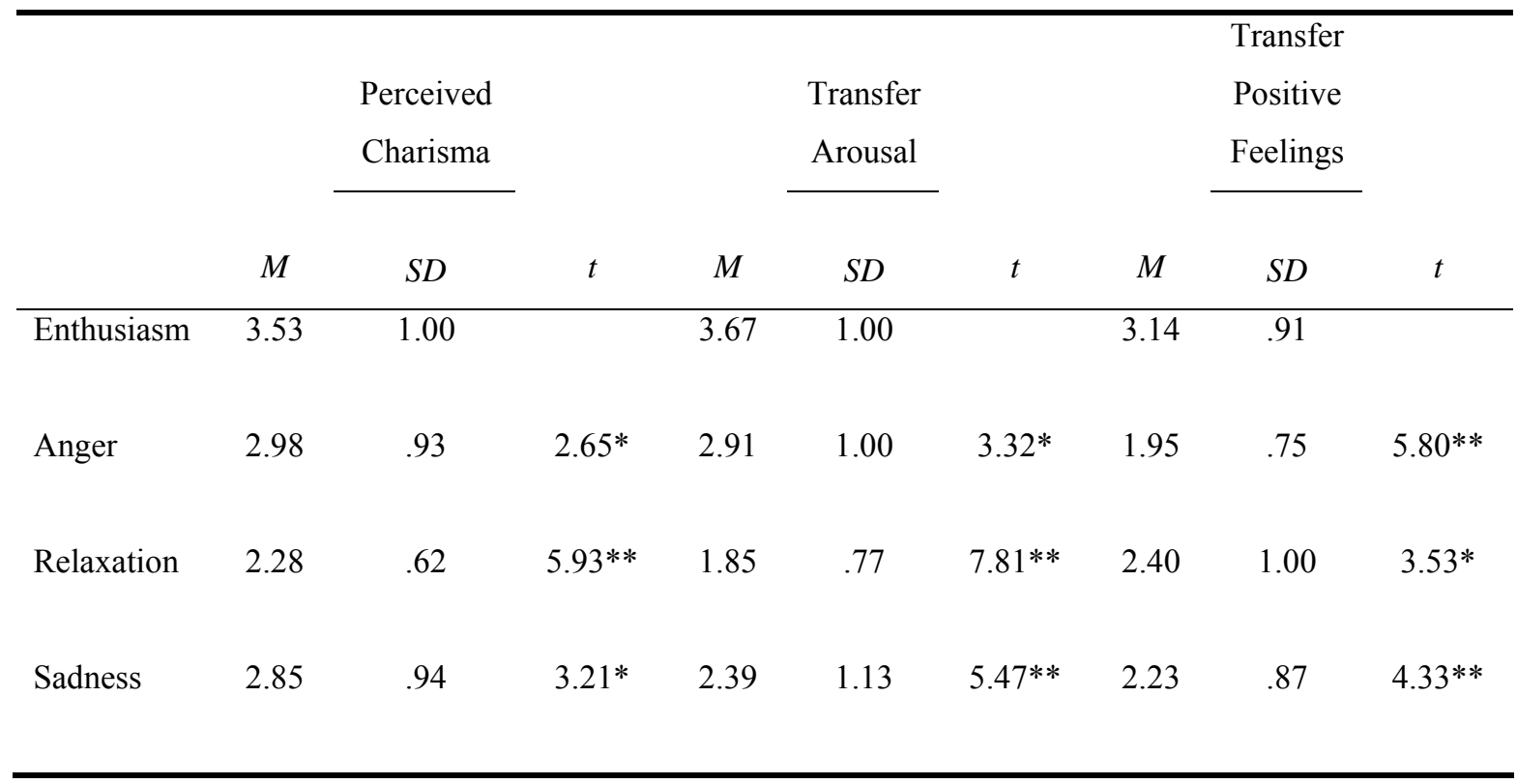

Note. ${ }^{*} p<.01 .{ }^{* *} p<.001 ;$ t-values are for comparisons of enthusiasm with the other affective displays. 
Table 2

Means, Standard Deviations, and Inter-correlations, Study 2.

\begin{tabular}{|c|c|c|c|c|c|c|c|c|c|}
\hline & & $M$ & $S D$ & 1 & 2 & 3 & 4 & 5 & 6 \\
\hline 1 & Enthusiasm & 3.75 & .97 & - & & & & & \\
\hline 2 & Anger & 2.20 & 1.04 & -.21 & - & & & & \\
\hline 3 & Relaxation & 3.23 & 1.05 & .16 & $-.44 * *$ & - & & & \\
\hline 4 & Sadness & 2.11 & 1.07 & -.21 & $-.38 * *$ & $.65^{* *}$ & - & & \\
\hline 5 & Transfer Arousal & 3.50 & .86 & $.44^{* *}$ & .19 & -.22 & $-.29 *$ & - & \\
\hline 6 & Transfer Positive Feelings & 3.72 & .87 & $.54 * *$ & .07 & $-.25^{*}$ & -.20 & $.68^{* *}$ & - \\
\hline 7 & Perceived Charisma & 3.57 & .90 & $.53^{* *}$ & .03 & -.22 & -.24 & $.73 * *$ & $.78^{* *}$ \\
\hline
\end{tabular}


Table 3

Results of Regression Analysis, Study 2.

\begin{tabular}{|c|c|c|c|c|c|c|c|c|c|c|c|c|}
\hline & \multirow{3}{*}{\multicolumn{2}{|c|}{$\begin{array}{l}\text { Perceived } \\
\text { Charisma }\end{array}$}} & \multirow[b]{4}{*}{$\beta$} & \multirow{3}{*}{\multicolumn{2}{|c|}{$\begin{array}{l}\text { Transfer } \\
\text { Arousal }\end{array}$}} & \multicolumn{6}{|c|}{ Transfer } & \multirow[b]{4}{*}{$\beta$} \\
\hline & & & & & & & & Positive & & & Perceived & \\
\hline & & & & & & & & Feelings & & & Charisma & \\
\hline & $B$ & $S E B$ & & $B$ & $S E B$ & $\beta$ & B & $S E B$ & $\beta$ & $B$ & $S E B$ & \\
\hline Enthusiasm & .52 & .10 & $.52 *$ & .39 & .10 & $.42 *$ & .50 & .10 & $.53 *$ & .12 & .09 & .12 \\
\hline Anger & -.12 & .13 & -.13 & .00 & .12 & .00 & -.19 & .12 & -.22 & -.04 & .09 & -.04 \\
\hline Relaxation & -.11 & .10 & -.12 & .05 & .10 & .06 & -.08 & .10 & -.09 & -.10 & .07 & -.11 \\
\hline Sadness & -.12 & .12 & -.13 & -.21 & .12 & -.24 & -.03 & .12 & -.03 & -.03 & .09 & -.03 \\
\hline Transfer of & & & & & & & & & & .39 & .11 & $.37^{*}$ \\
\hline Arousal & & & & & & & & & & & & \\
\hline Transfer of & & & & & & & & & & .46 & .11 & $.45^{*}$ \\
\hline Positive & & & & & & & & & & & & \\
\hline Feelings & & & & & & & & & & & & \\
\hline
\end{tabular}

Note. $R^{2}=.34$ for Step $1 ; R^{2}=.71$ for Step 2 ( $p s<.001$ ). The regression is significant, $F(6,60)=23.91, p<$

.001 . Effects marked with an asterisk are significant at $p<.001$; Difference in regression weights of

Enthusiasm vs. other 3 conditions on Transfer of Arousal, Transfer of Positive Feelings and Perceived

Charisma are all significant at .05 level (cf. Cohen \& Cohen, 1983). 


\section{Appendix}

\section{SIDEBAR: Organizational Context Study 1}

All participants in Study 1 were students of RSM Erasmus University, Erasmus University Rotterdam, a business school in the Netherlands. RSM Erasmus University is ranked in the top of European business schools, and the ambition of most students at the school, and presumably most participants in Study 1, is either a career in management or the start of their own business. For the study, they were invited to the Erasmus Behavioral Lab to make sure participants could work undisturbed by, and uninfluenced by, others.

\section{SIDEBAR: Organizational Context Study 2}

In Study 2, members of three small Dutch organizations were surveyed: a soft drinks manufacturer, an institution for mental health care, and the railway police. By surveying employees of such a diverse set of organizations, we hoped to ensure that our findings are not tied to any specific organizational context, type, or branch.

The soft drinks manufacturer produces and distributes juices, sports drinks, chocolate drinks, and yoghurt drinks. In Study 2, we only surveyed employees who fulfilled functions within the head-office, especially sales functions, marketing functions, HR functions, and logistic functions. The team of the mental health care institution that participated in our research consisted of psychologists that diagnosed and counseled people (adults) with complaints concerning mental health. People that worked for the railway police operated in the southern district of the country and their role was to maintain order around railway stations. Participants were all police officers. While the nature of the job differs widely between organizations in some aspects, employees from all three organizations have in 
common that they have direct contact with their external clients, and regular contact with their direct supervisor. For all three organizations, there did not appear to be special circumstances that could be expected to impact leaders' affective displays. 


\section{Publications in the ERIM Report Series Research* in Management}

\section{ERIM Research Program: "Organizing for Performance"}

2007

Leadership Behaviour and Upward Feedback: Findings From a Longitudinal Intervention

Dirk van Dierendonck, Clare Haynes, Carol Borrill and Chris Stride

ERS-2007-003-ORG

http://hdl.handle.net/1765/8579

The Clean Development Mechanism: Institutionalizing New Power Relations

Bettina B.F. Wittneben

ERS-2007-004-ORG

http://hdl.handle.net/1765/8582

How Today's Consumers Perceive Tomorrow's Smart Products

Serge A. Rijsdijk and Erik Jan Hultink

ERS-2007-005-ORG

http://hdl.handle.net/1765/8984

Product Intelligence: Its Conceptualization, Measurement and Impact on Consumer Satisfaction

Serge A. Rijsdijk, Erik Jan Hultink and Adamantios Diamantopoulos

ERS-2007-006-ORG

http://hdl.handle.net/1765/8580

Testing the Strength of the Iron Cage: A Meta-Analysis of Neo-Institutional Theory

Pursey P.M.A.R. Heugens and Michel Lander

ERS-2007-007-ORG

http://hdl.handle.net/1765/8581

Export Orientation among New Ventures and Economic Growth

S. Jolanda A. Hessels and André van Stel

ERS-2007-008-ORG

http://hdl.handle.net/1765/8583

Allocation and Productivity of Time in New Ventures of Female and Male Entrepreneurs

Ingrid Verheul, Martin Carree and Roy Thurik

ERS-2007-009-ORG

http://hdl.handle.net/1765/8989

Cooperating if one's Goals are Collective-Based: Social Identification Effects in Social Dilemmas as a Function of Goal-Transformation David De Cremer, Daan van Knippenberg, Eric van Dijk and Esther van Leeuwen

ERS-2007-010-ORG

http://hdl.handle.net/1765/9041

Unfit to Learn? How Long View Organizations Adapt to Environmental Jolts

Pursey P. M. A. R. Heugens and Stelios C. Zyglidopoulos

ERS-2007-014-ORG

http://hdl.handle.net/1765/9404

Going, Going, Gone. Innovation and Exit in Manufacturing Firms

Elena Cefis and Orietta Marsili

ERS-2007-015-ORG

http://hdl.handle.net/1765/9732 
High in the Hierarchy: How Vertical Location and Judgments of Leaders' Power are Interrelated

Steffen R. Giessner and Thomas W. Schubert

ERS-2007-021-ORG

http://hdl.handle.net/1765/9727

Contracts to Communities: a Processual Model of Organizational Virtue

Pursey P.M.A.R. Heugens, Muel Kaptein and J. van Oosterhout

ERS-2007-023-ORG

http://hdl.handle.net/1765/9728

Why Are Some Entrepreneurs More Innovative Than Others?

Philipp Koellinger

ERS-2007-024-ORG

http://hdl.handle.net/1765/9730

Stimulating Strategically Aligned Behaviour Among Employees

Cees B. M. van Riel, Guido Berens and Majorie Dijkstra

ERS-2007-029-ORG

http://hdl.handle.net/1765/10067

The Effectiveness of Business Codes: A Critical Examination of Existing Studies and the Development of an Integrated Research Model

Muel Kaptein and Mark Schwartz

ERS-2007-030-ORG

http://hdl.handle.net/1765/10150

Knowledge Spillovers and Entrepreneurs' Export Orientation

Dirk De Clercq, Jolanda Hessels and André van Stel

ERS-2007-038-ORG

http://hdl.handle.net/1765/10178

Silicon Valley in the Polder? Entrepreneurial Dynamics, Virtuous Clusters and Vicious Firms in the Netherlands and Flanders Willem Hulsink, Harry Bouwman and Tom Elfring

ERS-2007-048-ORG

http://hdl.handle.net/1765/10459

An Incomplete Contracting Model of Governance Structure Variety in Franchising

George Hendrikse and Tao Jiang

ERS-2007-049-ORG

http://hdl.handle.net/1765/10462

On the Evolution of Product Portfolio Coherence of Cooperatives versus Corporations: An Agent-Based Analysis of the Single Origin Constraint

George Hendrikse and Ruud Smit

ERS-2007-055-ORG

http://hdl.handle.net/1765/10505

Greenfield or Acquisition Entry: A Review of the Empirical Foreign Establishment Mode Literature

Arjen H.L. Slangen and Jean-François Hennart

ERS-2007-059-ORG

http://hdl.handle.net/1765/10539

Do Multinationals Really Prefer to Enter Culturally-Distant Countries Through Greenfields Rather than Through Acquisitions?

The Role of Parent Experience and Subsidiary Autonomy

Arjen H.L. Slangen and Jean-François Hennart

ERS-2007-060-ORG

http://hdl.handle.net/1765/10538 
The Financial Centres of Shanghai and Hong Kong: Competition or Complementarity?

Bas Karreman and Bert van der Knaap

ERS-2007-062-ORG

http://hdl.handle.net/1765/10516

Peer Influence in Network Markets: An Empirical Investigation

Jörn H. Block and Philipp Köllinger

ERS-2007-063-ORG

http://hdl.handle.net/1765/10540

Clustering in ICT: From Route 128 to Silicon Valley, from DEC to Google, from Hardware to Content Wim Hulsink, Dick Manuel and Harry Bouwman

ERS-2007-064-ORG

http://hdl.handle.net/1765/10617

Leader Affective Displays and Attributions of Charisma: The Role of Arousal

Frederic Damen, Daan van Knippenberg and Barbara van Knippenberg

ERS-2007-067-ORG

http://hdl.handle.net/1765/10621

Unity through Diversity: Value-in-Diversity Beliefs, Work Group Diversity, and Group Identification

Daan van Knippenberg, S. Alexander Haslam and Michael J. Platow

ERS-2007-068-ORG

http://hdl.handle.net/1765/10620

Entrepreneurial Diversity and Economic Growth

Ingrid Verheul and André van Stel

ERS-2007-070-ORG

http://hdl.handle.net/1765/10619

Commitment or Control? Human Resource Management Practices in Female and Male-Led Businesses Ingrid Verheul

ERS-2007-071-ORG

http://hdl.handle.net/1765/10618

* A complete overview of the ERIM Report Series Research in Management: https://ep.eur.nl/handle/1765/1

ERIM Research Programs:

LIS Business Processes, Logistics and Information Systems

ORG Organizing for Performance

MKT Marketing

F\&A Finance and Accounting

STR Strategy and Entrepreneurship 